\title{
Physical Activity in the Prevention and Therapy of Breast Cancer
}

\author{
Christine Graf Nicolas Wessely
}

Abteilung für Bewegungs- und Gesundheitsförderung, Institut für Bewegungs- und Neurowissenschaft, Köln, Germany Keywords
Breast cancer · Prevention · Therapy · Physical activity
Mechanisms

\section{Summary}

Numerous epidemiological and case-control studies have proven the efficacy of physical activity in the prevention of breast cancer. In physically active subjects, the risk reduction averaged $25-30 \%$. According to published data, 30-60 min of exercise per day at a moderate intensity is regarded as the optimal duration. Furthermore, physical activity plays an important role in the therapy of breast cancer, not only after finishing but already during treatment. Among experts, the evidence of a positive impact on the fatigue syndrome and on the quality of life is found sufficiently convincing. Now, the most recent investigations have shown that regular moderate exercise may bring about a prolongation of life. In the present publication, the most important background facts, potential mechanisms, and recommendations for the prevention and therapy of breast cancer are described.

\section{Background}

Breast cancer is the most common type of cancer in women in Germany and the most frequent cause of death induced by malignant tumors worldwide $[1,2]$. The relationship between physical activity and prevention of breast cancer has been proven by numerous epidemiological studies. The American Cancer Society assumes that around one-third of the yearly 500,000 malignant tumor-related deaths result from inactivity, high caloric intake, and overweight [3]. Large studies and meta-analyses demonstrated that physical activity reduces the risk of developing cancer in pre- as well as in postmenopausal

\section{Schlüsselwörter \\ Brustkrebs · Prävention · Therapie · Körperliche Aktivität · Mechanismen}

\section{Zusammenfassung}

Zahlreiche epidemiologische und Fall-Kontroll-Studien belegen inzwischen den Nutzen von körperlicher Aktivität in der Prävention des Mammakarzinoms. Bei sportlich Aktiven findet sich eine Risikoreduktion um etwa 25-30\%. Die optimale Dauer wird auf der Basis vorhandener Daten aktuell mit etwa 30-60 min pro Tag bei mittlerer Intensität angegeben. Aber auch in der Therapie des Mammakarzinoms spielt körperliche Aktivität eine wichtige Rolle, und zwar nicht erst nach abgeschlossener Chemotherapie, sondern auch bereits währenddessen. Gesichert sind die positiven Effekte auf das Fatigue-Syndrom bzw. die Lebensqualität. Erste Studien geben außerdem Hinweise, dass das Überleben durch regelmäßige moderate Bewegung verlängert wird. Im vorliegenden Beitrag wurden die wichtigsten Hintergründe, potenzielle Mechanismen sowie Empfehlungen für die Prävention und Therapie des Mammakarzinoms zusammengestellt.

women [4]. However, most of these studies were cohort or case-control studies and, thus, were rated as grade IIb-III on a standard scale of medical evidence. The question still remains unanswered which kind of activity in daily routine, in professional life, and in leisure time is preferable and possibly the most effective one. From the methodological perspective, already the quantification of physical activity is rather complicated and the results depend on the applied methods, i.e. questionnaires, fitness tests, etc. The particular design of the study must always be taken into consideration; therefore, having in mind the quality grades of evidence, a final conclusion cannot yet be drawn, except the one that physical activity at

\section{KARGER}

Fax +497614520714

Information@Karger.de

www.karger.com (c) 2010 S. Karger GmbH, Freiburg

Accessible online at:

www.karger.com/brc 
any level has a preventive impact. In addition to the presentation of recent research and publications focusing on prevention, therapy, and rehabilitation in the frame of this contribution, the underlying mechanisms are discussed.

\section{Preventive Aspects}

There is extensive research supporting the importance of the relationship between breast cancer and physical activity in professional life and leisure time. In most of the epidemiological studies, a consistent inverse relationship was observed. Friedenreich und Cust [4] recently produced a paper presenting the outcome of 62 studies dealing with the association of physical activity and breast cancer. In 47 of the 34 case-control and 28 cohort studies, the average risk reduction of developing the disease amounted to $25-30 \%$. In 28 of 33 research works, a positive dose-response relationship was reported. The maximum risk decrease was achieved by accumulating recreational activities $(-20 \%)$; however, this was also achieved by doing housework or pursuing lifetime activities such as brisk walking to the place of work or cycling $(-14 \%$ each) or by accumulating job-related activities $(-13 \%)$. How much physical activity is needed (duration and frequency) is only sparsely described in the literature. In most cases, the appropriate intensity is discussed. Thus, performing moderate activities decreased the risk of incidence by $22 \%$, and carrying out vigorous activities lowered the risk by $26 \%$. Friedenreich and Cust considered the timing and defined two groups, 1-2 years and 10-20 years, respectively, before confirming the diagnosis as well as different age groups (adolescence or early, middle and late adulthood). The latter classification turned out to be more promising; in particular, older women showed an advantage. Furthermore, different subgroup analyses revealed an activity-related benefit for pre- and postmenopausal women. An extra benefit was described for women with a body mass index $(\mathrm{BMI})<22 \mathrm{~kg} / \mathrm{m}^{2}$, for those with hormone receptor-negative tumors, for non-white women, and for mothers. An additional study that deals with the question of the appropriate amount of physical activity is the Nurses' Health Study. Women who reported to be moderately or vigorously active for 7 or more hours per week were compared to those who reported less than 1 hour per week. Those reporting 7 or more hours of activity had a $20 \%$ risk reduction of developing breast cancer. This association was similar in pre- and in postmenopausal women [5]. The variety of different results can be explained by considering the spectrum of parameters used to assess physical activity, as mentioned above. A more objective measure is to register the physical performance capacity assessed by using cycle ergometry or treadmill, which in turn is genetically determined.

\section{Conclusion and Recommendations for Prevention}

Any type of physical activity/exercise performed at any age decreases the risk of developing breast cancer; in particular, older and postmenopausal women with normal weight benefit from incorporating activities and a well-balanced nutrition in their way of life. Recently published recommendations with regard to primary prevention indicate that physical activities should be carried out for 30, or better 45-60 min/ day, on 5 days/week. Many studies demonstrated a doseresponse association; moderate-intensity physical activity (energy expenditure $>4.5$ metabolic equivalents of task (MET)), however, seemed to be more effective than low-intensity exercises $(<4.5 \mathrm{MET})$ [6]. It is supposed that it is not necessary to exercise continuously, to accumulate phases of physical activity in the course of a day in 10-min units is sufficient. The objective to maintain an active everyday life can already be the first step to greater physical activity and can facilitate the re-entry into a sportive life. Consequently, it is highly recommended to use stairs instead of elevators, to walk or to cycle to the place of work, to incorporate an active break into the work routine or to take for example some minutes off in order to take a walk, etc. The volume of these activities should be increased continuously until the above-mentioned 30-60 min of physical activity per day are reached [3].

\section{Possible Mechanisms}

The mechanisms of the effects of physical activity on the human organism are very complex and can only be explained in a broad context. At present, it is not yet possible to describe conclusively the interlocking biochemical pathways during workload, as the results of investigations performed in vitro could not be confirmed by those achieved on the basis of epidemiological studies.

Nevertheless, different possible influences shall be presented. First of all, acute and chronic workloads (in the sense of training) have an impact on various parts of the immune system. It is assumed that this is caused by the exerciseinduced release of hormones, in particular catecholamines and cortisol. As a consequence, the number of cells and, moreover, the function of cellular and humoral defense mechanisms change. This is mainly understood with regard to natural killer cells or cytotoxic $\mathrm{T}$ cells, but also to transmitters of the immune system, the so-called cytokines (e.g. C-reactive protein (CRP)) [7-9]. Among other things, catecholamines lead to a dose-dependent augmentation of natural killer (NK) cells by approximately $150-300 \%$ and of cytotoxic $\mathrm{T}$ cells by $50-100 \%$ [10]. However, within the first $2 \mathrm{~h}$ after workload, a strong decrease is observed. Basically, this effect occurs when cortisol is released, and it is an explanation why high load intensities provoke more prominent reactions. The low levels of monocytes and macrophages seen after intensive workloads sometimes even remain depleted for several days (s. 'open 
window'). The function of the NK cells may enhance by around $40-100 \%$ and decrease - according to the intensity by around $25-35 \%$ below baseline [11]. The phagocytic and cytotoxic functions of the macrophages seem to be enhanced especially after moderate physical activities. These findings do not yet provide sufficient evidence, but support the hypothesis that moderate physical activities in particular have a positive impact on the immune system $[12,13]$. New research is advancing the understanding of the correlation of physical activity and the development of malignant tumors, but up to now its benefit in prevention and in therapy has not been proven conclusively.

In addition, physical activity has great effects on sex hormones. Active women show lower concentrations of sex hormones and, hence, a decreased exposure to free estrogen $[13,14]$. Estrogens promote the risk of mammary cancer development, which is attributed to the stimulation of mitoses and the regulation of cell proliferation [15]. Progesterone and androgens may also favor the development of tumors, but this aspect has not been studied extensively, and the findings in the literature are contradictory regarding the importance of androgens for growth and diffusion of breast cancer cells [16-19].

Before menopause, the ovaries are the primary source of estrogen synthesis, whereas after menopause aromatized ovarian and adrenal androgens mainly contribute to the estrogen production. By aromatase, androgen precursor substances (testosterone, androstendione) are converted to estrogens [20]. This conversion occurs at extragonadal sites, predominantly in visceral adipose tissue [21]; therefore, the body composition, and especially the percentage of body fat, plays an important role in the prevention of developing breast cancer after menopause. Meanwhile, in the therapy of breast cancer patients, the administration of aromatase inhibitors is well established. They inhibit the conversion of androgens to estrogens. Investigations focusing on physical activity do not yet exist, but it can be suggested that synergistic effects may be expected.

In the context of body composition and visceral adipose tissue, the increased concentration of insulin is discussed, which influences the bioavailability of estrogens and androgens by down-regulating sex hormone-binding globulin (SHBG) and up-regulating ovarian hormone production. However, it should be considered that the growth hormones insulin and insulin-like growth factor-1 (IGF-1) themselves have an impact on carcinogenesis. Goodwin et al. [22] reported a relationship between higher levels of fasting insulin and an adverse prognostic factor for breast cancer in 512 women with diabetes mellitus. The tumorigenic effects of insulin can be directly relayed by insulin receptors to (pre-) neoplastic cells or they are a secondary consequence of hyperinsulinemia which leads to changes of the endogenous hormone metabolism. Insulin, for example, enhances the synthesis and biological actions of IGF-1 and thus is found to be an important factor in the pathogenesis of tumor diseases [23]. It is a potent mitogen that plays a decisive role in regulating apoptosis, proliferation, and differentiation of cells. According to a large number of epidemiological studies, this effect is associated with a higher incidence of mammary cancer risk [24]. The effects of IGF-1 are mainly mediated by the IGF-1 receptor. The latter is very similar to the insulin receptor $(60 \%$ homology). For this reason, both insulin and IGF-1 are able to activate both receptors. In addition, the effect of IGF-1 is regulated by IGF-binding proteins (IGFBPs). Among the 6 described IGFBPS [23], IGFBP-3 plays the most important role as it does not only control the mitogenic action of IGF-1 but also inhibit its antiapoptotic effect [25]. It has been scientifically proven that physical activity leads to improved insulin sensitivity, to a reduced level of insulin, and to an increased concentration of IGFBP-3 [26, 27]. Moreover, recent studies revealed positive effects of physical activity on the level of insulin in cancer after treatment. Ligibel et al. [27] demonstrated in 101 till then inactive overweight breast cancer patients who were randomly divided into a training group and a control group that the insulin level could be reduced significantly in the training group but not in the control group. However, an effect on fasting glucose and body composition could not be found.

More and more recent studies have identified the association between the adipocytokines leptin and adiponectin and the development of breast cancer. They represent 2 of around 100 factors that are secreted from visceral adipose tissue [28]. Leptin was detected in breast cancer tissue and in breast cancer cell lines and correlated positively with the body fat mass $[29,30]$. It is assumed that leptin stimulates mammary tumor cell growth. There is an ongoing discussion whether this process can be attributed to central nervous mechanisms, the promotion of angiogenesis, and an enhanced aromatase expression resulting in higher levels of estrogen [31]. The biological effect of leptin on the development and distribution of breast cancer can be attributed to the leptin-induced proliferation of mammary tumor cell lines, the increase of proteolytic enzymes that are necessary in the process of dissemination, and the stimulating effect on angiogenesis. Furthermore, leptin itself is able to promote aromatase expression and exerts its growth effects on estrogen receptor-positive human breast cancer cell lines by activating the mitogen-activated protein kinase (MAPK) pathway [32]. The impact of aromatase inhibitors on leptin is not yet well understood. A shortterm investigation of Lapauw et al. [33] revealed a reduction of the insulin level after administration of aromatase inhibitors in young and elderly male subjects already after 28 days, whereas these findings could not be confirmed by a study of Luukkaa et al. [34].

Adiponectin, however, shows opposite effects; it appears to enhance the insulin sensitivity [35] and to have an antiproliferative effect on breast cancer cells [36]. Whether the protective effect of a reduced body fat mass could be the decisive 
factor has not yet been sufficiently studied. However, it was reported that the adiponectin concentration was negatively associated with the body fat mass and increased when the body fat mass declined [37]. In contrast, investigations performed by Hulver et al. [38] revealed that physical activity that did not provoke any reduction in body fat mass did not result in any changes of the adiponectin concentrations.

Regarding cellular pathways, inflammatory processes are thought to play a pivotal role. Physical activity influences both systemically and locally the balance between pro- and antiinflammatory cytokines [13]. Exercise workloads, especially heavy loads, are regarded as inflammatory stimuli, but this reaction is compensated by adequate down-regulation processes. Further effects that probably depend on the duration and intensity of the respective exercise workload take place in signaling pathways, e.g. the effects of 5'-AMP-activated protein kinase (AMPK), phosphoinositide 3-kinase (PI3K), MAPK, and NF-kappaB [39]. These signaling pathways are extremely important when studying the development of mammary cancer as they are involved in different ways in the regulation of transcription, in the development of insulin resistance, apoptosis, infection, etc. However, it is not yet understood whether the influencing processes already take place on the DNA level [40].

\section{Physical Activity during Therapy}

An increasing number of investigations deal with the role of physical activity during tumor therapy. The disease and side effects of the therapy lead to a variety of negative effects on muscle strength, physical performance capacity, body composition, and mood. However, it has been shown that physical activity may counteract the loss of performance capacity and muscle strength, and may improve the mood [41]. Courneya et al. [42] conducted a study on 242 patients with breast cancer. They determined the effects of endurance and resistance training on the subjects during therapy compared to a treatment without special exercise. The chemotherapy averaged 17 weeks, and quality of life was the parameter they focused on. Secondary objectives were to gain insight into the patients' fatigue and fitness level, and the incidence of lymphedema. The group of 78 patients who performed an endurance training showed a boost in self-esteem, improved fitness, and a favorable shift in body composition compared to the control group $(\mathrm{n}=82)$. The resistance training group $(\mathrm{n}=82)$ could improve their self-esteem and their muscle strength as well. No incidence of lymphedema was reported. The authors could not reveal a direct effect on the fatigue syndrome or on the quality of life due to physical activity. Other studies, however, described positive effects on these two parameters as well [43].

\section{Physical Activity in Tertiary Prevention}

In Germany, approximately 436,000 new cases of individuals with malignant tumors are discovered each year. The 5-year survival rates have improved over the past years. Besides an early diagnosis, the improved therapy options and new measures of diagnostic techniques could increase the patients' chances of survival, but they also emphasize the necessity for adequate rehabilitation programs.

However, even after successful treatment, these patients are at increased risk of recurrence. Moreover, the therapy can cause side effects, and some of the individuals concerned may experience symptoms like breathlessness, fatigue or nausea because of which their quality of life can potentially be reduced. Without doubt, this background knowledge supports the importance of changing the lifestyle and taking up a healthy way of life, i.e. not to smoke, to reduce alcohol consumption, to decide on healthy nutrition and on physical activity.

Cancer survivors especially benefit from being physically active as it decreases the risk of recurrence and increases the survival rates $[43,44]$. However, in the USA, only one-third of the patients achieve the recommended amount of exercise of at least $150 \mathrm{~min} /$ week [45]. There is no statistical data available for Germany.

Various studies could show that cancer survivors $(\mathrm{n}=7384)$ did not follow a healthier way of life than the control participants $(n=121,347)$. Data from the National Health Interview Surveys documented that tumor patients did not consume less cigarettes and alcohol than the healthy controls, but the survivors were $9 \%$ more likely to engage in the recommended physical activity. These data help understand how important it is to guide cancer survivors to a healthy way of life and to provide subject-specific support [46].

\section{Recommendations for Therapy}

There is currently no clear evidence regarding the most recommendable kind of sports and the most adequate intensity and frequency in order to obtain a benefit in primary or tertiary prevention. Actually, in primary prevention, the aim is to encourage individuals to engage in at least 30-60 min of exercise on at least 5 days per week, as given in the recommendations of the American Cancer Society for the prevention of tumor diseases [47]:

- energy balance control

- physical activity for at least $30 \mathrm{~min}$, or better 45-60 min (adults), on at least 5 days per week, in addition to everyday activities

- well-balanced nutrition

-5 servings of fruits and vegetables per day

- moderate alcohol consumption (not more than 1 alcoholic drink for women and 2 drinks for men per day) 
In follow-up or tertiary prevention, endurance training at moderate intensities is most often recommended [48]. Moreover, it is aimed to follow the recommendations of primary prevention [49]. Carefully performed stretching exercises and gymnastics of about $10 \mathrm{~min}$ duration could be the first regimen for those patients who have been inactive before diagnosis and/or for those who are physically weak. Step by step they should then be taught to adopt a more active physical behavior throughout the day and to perform an exercise program that is tailored to the particular needs of the individual. Each form of exercise has characteristic benefits; however, when composing an exercise program, one must take into account each patient's specific limitations resulting from side effects after surgery, e.g. shoulder joint disorders provoked by breast amputation or lymph node resection. In these cases, physiotherapy must be included. If special exercises or physical activities cause disorders, they should be altered, performed at reduced intensities or stopped. In case of severe anemia or thrombocytopenia, any kind of exercise should be discontinued until the patient's condition has improved, and patients with poor immune function should avoid close contact to other people in public sports facilities. Appropriate attention will also have to be paid to patients with lymphedema and metastases.

It is very helpful to put patients in touch with specific outpatient groups (the Deutsche Krebsgesellschaft/German Cancer Society www.krebsgesellschaft.de) or sports organizations, e.g. regional sports clubs or self-help groups, in order to reduce the anxiety and uncertainty as well as the excessive demands they are often faced with.

\section{Conclusion and Perspective}

The relationship between physical activity and reduction of breast cancer incidence has been extensively studied, but at the moment it is not yet clear which of the underlying mechanisms have protective effects. Especially, more research is needed to understand what kinds of physical activity at which duration, frequency and intensity provide these benefits. However, existing evidence shows positive adaptations induced by any level of physical activity. Besides psychosocial aspects, the influence on the body composition, characterized by an increase or maintenance of muscle mass and a decrease in fat mass, has been described to play a central role. These results and the rising number of cancer patients strongly support the need for establishing additional sports groups to meet the demands. The most important aim is to improve the individual's motivation to exercise. In the long term, only those persons who engage in regular physical activity with a high extent of motivation will benefit from exercise, independent of what they have chosen, jogging unaccompanied, walking in nature, or joining sports friends in the gym.

\section{Conflict of Interest}

The authors declare no conflict of interest.

\section{References}

1 Schön D, Bertz J, Görsch B, Haberland J, Kurth BM: Die Dachdokumentation Krebs. Eine Surveillance-Einrichtung der Krebsregistrierung in Deutschland. Bundesgesundheitsblatt Gesundheitsforschung Gesundheitsschutz 2004;47:429-436.

2 Parkin DM, Bray F, Ferlay J, Pisani P: Global Cancer Statistics, 2002. CA Cancer J Clin 2005; 55:74-108.

3 Kushi HL, Byers T, Doyle C, Bandera EV, McCullough M, Gansler T, Andrews KS, Thun MJ: American Cancer Society guidelines on nutrition and physical activity for cancer prevention: reducing the risk of cancer with healthy food choices and physical activity. CA Cancer J Clin 2006;56:254281.

4 Friedenreich CM, Cust AE: Physical activity and breast cancer risk: impact of timing, type and dose of activity and population sub-group effects. Br J Sports Med 2008;42:636-647.

$\checkmark 5$ Colditz GA, Hankinson SE: The Nurses' Health Study: Lifestyle and health among women. Nat Rev Cancer 2005;5:388-396.

6 Thune I, Furberg AS: Physical activity and cancer risk: dose-response and cancer, all sites and sitespecific. Med Sci Sports Exerc 2001;33:S530-S550.

7 Westerlind KC: Physical activity and cancer prevention - mechanisms. Med Sci Sports Exerc 2003;35:1834-1840.
8 Benschop RJ, Rodriguez-Feuerhahn M, Schedlowski M: Catecholamine-induced leukocytosis: early observations, current research, and future directions. Brain Behav Immun 1996;10:77-91.

$\checkmark 9$ Shephard RJ, Shek PN: Potential impact of physical activity and sport on the immune system - a brief review. Br J Sports Med 1994;28:247-255.

10 Nieman DC: Exercise, upper respiratory tract infection, and the immune system. Med Sci Sports Exerc 1994;26:128-139.

11 Nieman DC, Miller AR, Henson DA, Warren BJ, Gusewitch G, Johnson RL, Davis JM, Butterworth DE, Nehlsen-Cannarella SL: Effects of high- vs moderate-intensity exercise on natural killer cell activity. Med Sci Sports Exerc 1993;25:1126-1134.

12 Pedersen BK, Hoffman-Goetz L: Exercise and the immune system: regulation, integration and adaptation. Physiol Rev 2000;80:1055-1081.

13 McTiernan A: Mechanisms linking physical activity with cancer. Nat Rev Cancer 2008;8:205-211.

14 Coyle YM: Physical activity as a negative modulator of estrogen-induced breast cancer. Cancer Causes Control 2008;19:1021-1029.

15 Doisneau-Sixou SF, Sergio CM, Carroll JS, Hui R, Musgrove EA, Sutherland RL: Estrogen and antiestrogen regulation of cell cycle progression in breast cancer cells. Endocr Relat Cancer 2003;10:179-186.
16 Zeleniuch-Jacquotte A, Shore RE, Koenig KL, Akhmedkhanov A, Afanasyeva Y, Kato I, Kim MY, Rinaldi S, Kaaks R, Toniolo P: Postmenopausal levels of oestrogen, androgen, and SHBG and breast cancer: long-term results of a prospective study. Br J Cancer 2004;90:153-159.

17 Secreto G, Toniolo P, Berrino F, Recchione C, Cavalleri A, Pisani P, Totis A, Fariselli G, Di Pietro S: Serum and urinary androgens and risk of breast cancer in postmenopausal women. Cancer Res 1991;51:2572-2576.

18 Grattarola R, Secreto G, Recchione C, Castellini $\mathrm{W}$ : Androgens in breast cancer. II. Endometrial adenocarcinoma and breast cancer in married postmenopausal women. Am J Obstet Gynecol 1974;118:173-178.

19 Grattarola R: Androgens in breast cancer. I. A typical endometrial hyperplasia and breast cancer in married premenopausal women. Am J Obstet Gynecol 1973;116:423-428.

20 Crohns C, Bauerschlag D, Maass N: Endokrine Therapie des Mammakarzinoms. Gynakologe 2009;42:164-169.

21 Karaer O, Oruc S, Koyuncu FM: Aromatase inhibitors: possible future applications. Acta Obstet Gynecol Scand 2004;83:699-406. 
22 Goodwin P, Ennis M, Pritchard K, Trudeau ME, Koo J, Madarnas Y, Hartwick W, Hoffman B, Hood N: Fasting insulin and outcome in early stage breast cancer: Results of a prospective cohort study. J Clin Oncol 2002;20:42-51.

23 Yu H, Rohan T: Role of the insulin-like growth factor family in cancer development and progression. J Natl Cancer Inst 2000;92:1472-1489.

24 Hankinson SE, Willett WC, Colditz GA, Hunter DJ, Michaud DS, Deroo B, Rosner B, Speizer FE, Pollak M: Circulating concentrations of insulin-like growth factor-I and risk of breast cancer. Lancet 1998;351:1393-1396.

25 Ma J, Pollak MN, Giovanucci E, Chan JM, Tao Y, Hennekens CH, Stampfer MJ: Prospective study of colorectal cancer risk in men and plasma levels of insulin-like growth factor (IGF)-I and IGF-binding protein-3. J Natl Cancer Inst 1999;91:620-625.

-26 Irwin ML, Varma K, Alvarez-Reeves M, Cadmus L, Wiley A, Chung GG, DiPietro L, Mayne ST, Yu $\mathrm{H}$ : Randomized controlled trial of aerobic exercise on insulin and insulin-like growth factors in breast cancer survivors: the Yale Exercise and Survivorship study. Cancer Epidemiol Biomarkers Prev 2009;18:306-313.

27 Ligibel JA, Campbell N, Partridge A, Chen WY, Salinardi T, Chen H, Adloff K, Keshaviah A, Winer EP: Impact of a mixed strength and endurance exercise intervention on insulin levels in breast cancer survivors. J Clin Oncol 2008;26:907912.

28 Klöting N, Sturmvoll M, Blüher M: Biologie des viszeralen Fetts. Internist 2007:48:126-133.

29 Chilliard Y, Bonnet M, Delavaud C, Faulconnier Y, Leroux C, Djiane J, Bocquier F: Leptin in ruminants. Gene expression in adipose tissue and mammary gland, and regulation of plasma concentration. Domest Anim Endocrinol 2001;21:271-295.

-30 O'Brien SN, Welter BH, Price TM: Presence of leptin in breast cell lines and breast tumors. Biochem Biophys Res Commun 1999;259:695-698.

31 Garofalo C, Surmacz E: Leptin and cancer. J Cell Physiol 2006;207:12-22.
32 Housa D, Housová J, Verenová Z, Haluzík M: 233-244.

33 Lapauw B, T'Sjoen G, Mahmoud A, Kaufman JM, Ruige JB: Short-term aromatase inhibition: effects on glucose metabolism and serum leptin levels in young and elderly men. Eur J Endocrinol 2009;160:397-402.

34 Luukkaa V, Rouru J, Ahokoski O, Scheinin H, Irjala K, Huupponen R: Acute inhibition of oestrogen biosynthesis does not affect serum leptin levels in young men. Eur J Endocrinol 2000;142:164-169.

35 Lihn S, Pedersen SB, Richelsen B: Adiponectin: action, regulation and association to insulin sensitivity. Obes Rev 2005;6:13-21.

36 Arditi JD, Venihaki M, Karalis KP, Chrousos GP: Antiproliferative effect of adiponectin on MCF7 breast cancer cells: a potential hormonal link between obesity and cancer. Horm Metab Res 2007;39:9-13.

37 Yamauchi T, Kamon J, Waki H, Terauchi Y, Kubota N, Hara K, Mori Y, Ide T, Murakami K, Tsuboyama-Kasaoka N, Ezaki O, Akanuma Y, Gavrilova O, Vinson C, Reitman ML, Kagechika H, Shudo K, Yoda M, Nakano Y, Tobe K, Nagai R, Kimura S, Tomita M, Froguel P, Kadowaki T: The fat-derived hormone adiponectin reverses insulin resistance associated with both lipoatrophy and obesity. Nat Med 2001;7:941-946.

38 Hulver MW, Zheng D, Tanner CJ, Houmard JA, Kraus WE, Slentz CA, Sinha MK, Pories WJ, MacDonald KG, Dohm GL: Adiponectin is not altered with exercise training despite enhanced insulin action. Am J Physiol Endocrinol Metab 2002;283:E861-E865.

39 Petersen AMW, Pedersen BK: The anti-inflammatory effect of exercise. J Appl Physiol 2005; 98:1154-1162.

40 Lawrence MC, Jivan A, Shao C, Duan L, Goad D, Zaganjor E, Osborne J, McGlynn K, Stippec S, Earnest S, Chen W, Cobb MH: The roles of MAPKs in disease. Cell Res 2008;18:436-442.

41 Dimeo FC: Körperliche Aktivität und Krebs - eine Übersicht. Dtsch Z Sportmed 2001;52:238-244.
2 Courneya KS, Segal RJ, Mackey JR, Gelmon K, Reid RD, Friedenreich CM, Ladha AB, Proulx C, Vallance JKH, Lane K, Yasui Y, McKenzie DC: Effects of aerobic and resistance exercise in breast cancer patients receiving adjuvant chemotherapy: a multicenter randomized controlled trial. J Clin Oncol 2007;25:4396-4404.

43 McNeely ML, Campbell KL, Rowe BH, Klassen TP, Mackey JR, Courneya KS: Effects of exercise on breast cancer patients and survivors: a systematic review and meta-analysis. CMAJ 2006;175:34-41.

44 Holmes MD, Chen WY, Feskanich D, Kroenke $\mathrm{CH}$, Coldith GA: Physical activity and survival after breast cancer diagnosis. JAMA 2005;293: 2479-2486.

45 Irwin ML, Ainsworth BE: Physical activity interventions following cancer diagnosis: methodologic challenges to delivery and assessment. Cancer Invest 2004:22:30-50.

46 Bellizzi KM, Rowland JH, Jeffrey DD, McNee T: Health behaviors of cancer survivors: examining opportunities for cancer control intervention. J Clin Oncol 2005;23:8884-8893.

47 Eyre H, Kahn R, Robertson RM: American Cancer Society, the American Diabetes Association, and the American Heart Association. Collaborative Writing Committee. Preventing cancer, cardiovascular disease, and diabetes: a common agenda for the American Cancer Society, the American Diabetes Association, and the American Heart Association. Diabetes Care 2004;27:1812-1824.

48 Brown JK, Byers T, Doyle K, Courneya KS, Demark-Wahnefried W, Kushi LH, McTiernan A, Rock CL, Aziz N, Bloch AS, Eldridge B, Hamilton K, Katzin C, Koonce A, Main J, Mobley C, Morra ME, Pierce MS, Sawyer KA: Nutrition and physical activity during and after cancer treatment: an American Cancer Society guide for informed choices. CA Cancer J Clin 2003;53:268-291.

49 Doyle C, Kushi HL, Byers T, Courneya KS, Demark-Wahnefried W, Grant B, McTiernan A, Rock CL, Thompson C, Gansler T, Andrews KS: Nutrition and physical activity during and after cancer treatment: an American Cancer Society guide for informed choice. CA Cancer J Clin 2006;56:323-353. 